\title{
PERSPEKTIF HUKUM ISLAM MENGENAI PERNIKAHAN DINI AKIBAT SANKSI ADAT DI DESA POWELUA KECAMATAN BANAWA TENGAH KABUPATEN DONGGALA
}

\author{
M. Ikhsan.*
}

\begin{abstract}
This paper discusses early marriage due to Kaili's customary sanctions in the perspective of Islamic law (Case Study of Powelua Village, Banawa Tengah District, Donggala Regency). The problem to be examined in this research is how early marriage due to kaili customary sanctions in Powelua Village, Kec. Central Banawa District. Donggala and how is the perspective of Islamic law regarding early marriage due to kaili customary sanctions in Powelua Village, Kec. Central Banawa District. Donggala. The research method used in this research is a type of qualitative research, namely the type of research used to examine the conditions of natural objects. The results showed that, early marriage due to customary sanctions (adat ni soko ni po porongo or being arrested by marriage) in Poweluwa Village was already in effect before the spread of Islam in Central Sulawesi in particular, this customary sanction is an inviolable customary sanction starting from ancient times to the present. Marriage due to customary sanctions does not only occur for those who are brought age but marriages due to this customary
\end{abstract}


sanction do not know the age of anyone who is found to have violated customary sanctions so there are only two options, namely paying a fine (givu) or having a marriage (ni soko ni po porongo)

Keywords: Islamic law, marriage, Kaili

\section{A. Pendahuluan}

Nikah merupakan salah satu asas pokok hidup yang paling utama dalam masyarakat yang sempurna. Karakteristik khusus dalam Islam bahwa setiap ada perintah untuk dikerjakan oleh umatnya pasti telah ditentukan syariatnya (tata cara dan petunjuk pelaksanaannya), serta hikmah yang dikandung dari perintah tersebut. Sehingga tidak ada satu perintahpun dalam berbagai aspek kehidupan ini, baik yang menyangkut masalah ibadah secara khusus seperti perintah shalat, puasa, haji, dan lainnya, maupun yang berkaitan dengan ibadah secara umum seperti perintah mengeluarkan infaq, berbakti kepada orang tua, berbuat baik kepada tetangga, yang tidak memiliki syariat, dan hikmanya. Sama halnya dengan menikah, ia merupakan perintah Allah Swt untuk seluruh hamba-Nya tanpa terkecuali dan telah menjadi sunnah Rasul-Nya, maka sudah tentu ada syariatnya, dan hikmahnya.

Dalam kehidupan zaman modern ini dapat kita lihat pengaruh adat istiadat terhadap sanksinya yang berlaku di sebuah suku di negara Indonesia khususnya Provinsi Sulawesi Tengah. Sulawesi Tengah terdapat beberapa suku baik itu suku Bugis, Jawa akan tetapi suku asli di Sulawesi Tengah adalah suku Kaili. Suku bukan hanya satu suku saja, namun suku kaili terdapat beberapa macam seperti kaili rai, kaili doiriyah, kaili pu, kaili unde , dan masih banyak lagi suku kaili yang lainnya.

Salah satu suku kaili yang masih menerapkan pernikahan dini akibat sanksi adat adalah masyarakat Desa Powelua Tengah Kabupaten Donggala Kecamatan Banawa Tengah Sulawesi Tengah. Adat istiadat kaili unde salah satu adat yang ada di desa Powelua Kecamatan Banawa Tengah Kabupaten Donggala, dimana adat istiadat ini terdapat sanksi yang diberikan kepada masyarakat yang melanggar dalam peraturan yang ditetapkan oleh aturan adat istiadat 
suku kaili unde khususnya di desa powelua, salah satu aturan adat istiadat di desa powelua adalah ketika seorang remaja yang ditemukan berduaan antara laki-laki dan perempuan disebuah tempat yang jauh dari keramaian bahkan ditempat yang tidak terdapat sebuah lampu atau cahaya, biasanya remaja yang suka berpergian ditempat sunyi ini ialah remaja yang berpacaran dan meskipun mereka tidak berpacaran tapi ketika jalan berduaan ketempat yang telah dilarang, maka mereka berdua akan dikenakan sanksi adat yaitu harus dinikahkan. ${ }^{1}$

Sanksi adat ini dinamakan ni soko ni po porongo (ditangkap dikasi nikah). ${ }^{2}$ Sanksi adat yang diberikan kepada kedua anak remaja itu tidaklah mengenal umur terhadap yang melanggar hukum adat tersebut, maka terdapatlah sebuah masalah yang bertentangan dengan hukum Islam yaitu pernikahan dini. Sanksi adat kaili khususnya kaili unde banyak dilanggar oleh remaja-remaja dibawah umur berkisaran antara umur, bagi perempuan antara umur 13 s/d 15 tahun dan bagi laki-laki antara umur 15 s/d 18 tahun. ${ }^{3}$ Remaja-remaja yang di bawah umur tersebut rata-rata adalah anak remaja yang menempuh pendidikan atau yang menuntut ilmu. Sanksi adat ini tidak dapat lagi ditoleransi oleh kedua orang tua remaja-remaja yang melanggar aturan adat tersebut, hanya saja kedua orang tua anak remaja itu agar melaksanakan sanksi adat tersebut yaitu pernikahan.

Peneliti menggunakan jenis penelitian kualitatif ini karena fokus penelitian dalam tulisan ini bersifat mendeskripsikan, yaitu data yang diwujudkan dengan penafsiran data yang satu dengan yang lain kemudian menghubungkan data tersebut dalam bentuk kata-kata atau kalimat naratif.

Ringkasnya, sebagai permasalahan yang ingin di fokuskan dalam penelitian ini adalah untuk mengetahui tinjauan Hukum Islam mengenai pernikahan dini akibat sanksi adat di Desa Powelua

${ }^{1}$ Linda, (Masyarakat), Wawancara Pribadi, Desa Powelua Kec. Banawa Tengah Kab. Donggala, 21 Juli 2018.

${ }^{2}$ Cici, (Masyarakat), Wawancara Pribadi, Desa Powelua Kec. Banawa Tengah Kab. Donggala, 21 Juli 2018.

${ }^{3}$ Hasna (Masyarakat), Wawancara Pribadi, Desa Powelua Kec. Banawa Tengah Kab. Donggala, 21 Juli 2018 
Kecamatan Banawa Tengah Kabupaten Donggala Adapun tujuan dalam penelitian adalah pengetahuan, dan pemahaman yang berkenaan dengan pertanyaan dalam rumusan masalah tersebut.

\section{B. Pembahasan.}

\section{Pernikahan Dini Akibat Sanksi Adat Kaili Unde Desa Powelua.}

Pernikahan adalah salah satu kebutuhan atau yang diiginkan oleh setiap manusia yang berfikir untuk memenuhi kehidupan selanjutnya. Pernikahan dini merupakan pernikahan yang dilaksanakan yang usia kedua calon mempelai belum mencapai kedewasaan. Adapun pernikahan dini yang terjadi di desa Powelua yang disebabkan sanksi adat itu tidak mengenal umur hal ini dikemukakan oleh ketua adat desa powelua bahwa pernikahan akibat Sanksi adat ini sudah berlaku sebelum penyebaran agama Islam di Sulawesi Tengah khususnya Desa Powelua, sanksi adat ini merupakan sanksi adat yang tidak dapat diganggu gugat mulai dari zaman dahulu hingga saat ini. Pernikahan akibat sanksi adat tidak hanya terjadi untuk yang dibawa umur akan tetapi pernikahan akibat sanksi adat ini tidaklah mengenal umur siapa saja yang didapati melanggar sanksi adat maka hanya ada dua pilihan yaitu membayar denda (givu) atau melakukan pernikahan (ni soko ni po porongo).$^{4}$

Lebih lanjut lagi dikemukakan oleh tokoh agama bahwa;

Pernikahan akibat sanksi adat merupakan sesuatu yang sakral karena pernikahan akibat sanksi adat tidaklah mengenal umur siapapun dapat dikenai sanksi adat, samksi adat ini dapat berupa pernikahan atau denda akan tetapi pada realitanya kebanyakan dari mereka yang dikenai sanksi adat memilih untuk menikah dengan alasan bahwa biaya denda yang dipatok terkesan cukup memakan biaya dibandingkan dengan melaksanakan pernikahan. ${ }^{5}$

\footnotetext{
${ }^{4}$ Julmin (Ketua Adat), Wawancara Pribadi di Rumah, 16 September 2020

5 Ahmad (Tokoh Agama), Wawancara Pribadi di Rumah, 17 September 
Hal yang serupa diungkapkan oleh salah satu masyarakat bahwa,

Kebanyakan atau sekitar $80 \%$ masyarakat yang didapati melanggar adat lebih memilih nikah dari pada denda, karena dari pihak laki-laki berpikir jika memilihi denda maka akan mengeluarkan biaya yang cukup banyak sedangkan untuk pernikahan tidaklah sebanyak yang dikeluarkan dengan alasan adanya dispensasi bagi pasangan yang melanggar jika lebih memilih pernikahan akan disesuaikan dengan kemampuan lakilaki. ${ }^{6}$

Adapun sanksi-sanksi adat yang dapat menyebabkan pernikahan dini dikemukakan oleh ketua adat sebagai berikut: ${ }^{7}$

1. Pacaran ditempat gelap atau sunyi

2. Pacaran di atas jam 10 malam

3. Mengatar pacar atau perempuan di atas jam 10 malam

4. Berpeganggan tangan atau memesraan antara laki-laki dan perempuan

5. Hamil di luar nikah

6. Menyentuh kemaluan perempuan baik disengaja ataupun tidak, dalam hal ini tergantung dari perempuan jika perempuan tidak merasa keberatan atas sikap laki-laki tersebut dan mempercayai bahwa hal ini merupakan unsur ketidaksengajaan maka si lakilaki tidak akan diberikan sanksi akan tetapi jika justru sebaliknya perempuan merasa keberatan maka si laki-laki akan diberikan pilihan apakan memilih denda atau melangsungkan pernikahan

7. Didapati mencium perempuan (pacaran)

8. Kedapatan berzina

Proses bagi pasangan yang melanggar aturan adat sebagai berikut:

1. Jika di dapati oleh masyarakat 1 orang atau lebih, yang melihat pelaku yang melanggar adat tersebut, maka orang yang melihatnya tadi melapor ke ketua adat, kemudian ketua adat menyuruh orang yang melihat tadi untuk memanggil kedua orang tua dari dua pasangan yang melanggar aturan adat beserta anak-anak mereka yang melanggar aturan adat.

\footnotetext{
${ }^{6}$ Makir (Masyarakat), Wawancara Pribadi di Rumah, 18 September 2020
}

${ }^{7}$ Julmin (Ketua Adat), Wawancara Pribadi di Rumah, 18 September 2020 
2. Terjadilah diskusi antara ketua adat dengan kedua orang tua pasangan yang melanggar hukum adat, yang didiskusikan adalah masalah kedua pasangan yang didapati seperti, pacaran di tempat gelap, pacaran di atas jam 10 malam, mengatar pacar atau perempuan di atas jam 10 malam, dan hamil di luar nikah. Maka ketua adat menyampaikan pelanggaran tersebut sudah tidak wajar dan melanggar aturan-aturan yang telah ditetapkan, agar tidak terlanjur kebiasaan anak-anak ini maka lebih baik dinikahkan atau diberikan denda. Kedua orang tua pasangan tersebut secara aturan adat tidak dapat membantah kepada ketua adat, sehingga orang tua juga berdiskusi kepada masing-masing keluarga untuk menetapkan antara membayar denda atau melaksanakan pernikahan

3. Ketua adat memberikan pilihan kepada pelaku yaitu melaksanakan pernikahan atau membayar denda

4. Jika suka sama suka maka dinikahkan, mayoritas pelaku yang dikenai sanksi adat lebih memilih dinikahkan dari pada membayar denda, karena orang tua dari laki-laki merasa denda mengeluarkan uang yang tidak sedikit maka lebih baik nikah sekalian.

5. Setelah diskusi panjang antara ketua adat dengan orang tua dari kedua pasangan tersebut, maka kedua orang tua pasangan tadi mempersiapkan acara pernikahan anak-anak mereka.

6. Yang menetapkan tanggal pernikahan adalah ketua adat yang ditempati melapor. ${ }^{8}$

Dalam proses pernikahan jika kedua pasangan yang melanggar dan kedua orang tua telah sepakat untuk menikahkan mereka, untuk pelaku yang didapati melangar sanksi adat diatas umur 20 tahun maka ketentuan yang berlaku seperti prosedur dalam agama Islam, ${ }^{9}$ akan tetapi untuk pelaku yang dibawah umur maka kedua pasangan tersebut dicurikan umur. Namun dari tahun 2019 sudah tidak dapat lagi curi umur, sehingga kedua pasangan yang masih di bawah umur dinikahkan oleh pak Imam atau orang tua perempuan. ${ }^{10}$

\footnotetext{
${ }^{8}$ Julmin (Ketua Adat), Wawancara Pribadi di Rumah, 18 September 2020

9 Ahmad (Tokoh Agama), Wawancara Pribadi di Rumah, 19 September

${ }^{10}$ Ahmad (Tokoh Agama), Wawancara Pribadi di Rumah, 19 September 
Adapun alasan diberlakukan sanksi adat yang dikemukakan oleh ketua adat yaitu dapat membuat sial kampung, untuk mencegah perzinahan, untuk mencegah timbulnya fitnah, untuk menghindari konflik antar dua keluarga yang bermasalah. Lebih lanjut lagi dikemukakan oleh tokoh agama alasan diberlakukan sanksi adat ini adalah untuk menghindari agar kejadian-kejadian yang tidak diinginkan seperti memalukan orang tua, keluarga dan desa tidak lagi di lakukan dan untuk tetap menjaga keamanan kampung dari doktrindoktrin dari luar.

\section{Perspektif Hukum Islam Mengenai Pernikahan Dini Akibat Sanksi Adat di Desa Powelua}

Salah satu kajian yang begitu signifikan dan memiliki peranan dalam kerangka metodologi hukum Islam adalah al- 'urf, dalam ushul fiqh ini dapat menjadi acuan hukum yang diambil dari tradisi-tradisi sebuah masyarakat tertentu.

'Urf secara etimologi berarti "sesuatu yang dipandang baik dan diterima oleh akal sehat". "Urf adalah bentuk-bentuk muamalah yang telah menjadi kebiasaan dan telah berlangsung konsisten ditengah masyarakat. ${ }^{12}$ 'Urf juga juga disebut apa yang sudah terkenal dikalangan umat manusia dan selalu diikuti baik 'urf perkataan maupun perbuatan. ${ }^{13}$

'Urf ialah sesuatu yang telah dikenal oleh manusia dan telah menjadi tradisinya, baik berupa ucapan atau perbuatannya dan atau hal yang meninggalkan sesuatu yang juga disebut adat. ${ }^{14}$ Menurut Para Ulama 'urf juga dinamakan adat.

Dengan demikian adat dapat diterima atau dapat dijadikan sebagai hukum dengan syarat sesuatu tidak bertentangan dengan aqidah dan syariat Islam

${ }^{11}$ Rasyad Hasan Khalil, Tarikh Tasyri', (Jakarta; Amzah, 2009), h. 167

${ }^{12}$ Abu Zahro, Ushul Fiqh, (Surabaya; Pustaka Firdaus, 2011), h. 416

${ }^{13}$ Sulaiman Abdullah, Sumber Hukum Islam, (Jakarta; Sinar Grafika, 1995), h. 77

14 Abdul Wahhab Khallaf, Kaidah-Kaidah Hukum Islam (Ilmu Ushulul Fiqhi), (Jakarta;PT. Raja Grafindo Persada, 1996), h.133 
Pernikahan dini akibat sanksi adat yang sesuatu yang sakral karena pernikahan akibat sanksi adat di Desa Poweluwa tidaklah mengenal umur siapapun dapat dikenai sanksi adat, sanksi adat ini bersifat mengikat sehingga hanya ada dua pilihan yaitu antara menikah dan membayar denda. Jika ingin melihat dari esensi dari pernikahan itu sendiri bahwa pernikahan adalah jalan yang amat mulia untuk mengatur kehidupan rumah tangga dan keturunan, tetapi juga dapat dipandang sebagai satu jalan pintu pergenalan antara satu kaum dengan kaum lainnya, dan perkenalan itu akan menjadi jalan untuk menyampaikan pertolongan antara satu dengan yang lainnya. ${ }^{15}$ Dengan kata lain pernikahan suatu ikatan yang jika ditelusuri merupakan suatu kebaikan yang berjalan terus menerus.

Dengan demikian, jika pernikahan dijadikan sebagai sanksi adat maka hal itu dapat menghilangkan hakikat dari tujuan pernikahan itu sendiri dengan alasan bahwa dalam sanksi adat menyebabkan pernikahan bisa jadi terdapat unsur paksaan sedangkan dalam syarat pernikahan itu sendiri yaitu adanya kerelaan (tidak ada unsur paksaan) baik dari calon mempelai pria maupun wanita terlebih lagi jika menikah dibawah umur (pernikahan dini) hal itu dapat menimbulkan beberapa faktor kemudharatan yaitu:

1. Tidak stabilnya (kurang dewasa) pemikiran sehingga dapat menimbulkan retaknya rumah tangga bahkan bisa menyebabkan perceraian.

2. Belum siapnya organ-organ reproduksi wanita untuk hamil dan melahirkan

Usia pernikahan dini yang terdapat di Desa Powelua bagi lakilaki berumur 14-18 sedangkan bagi perempuan berumur 13-18 tahun, jika ingin melihat di kitab-kitab fiqhi tidak ditemukan mengenai batasan usia untuk melangsungkan pernikahan hanya saja syarat bagi kedua mempelai yang ingin melangsungkan pernikahan yaitu telah mencapai usia yang layak untuk melangsungkan pernikahan ${ }^{16}$ atau kedua belah pihak yang melaksanakan akad hendaknya cakap dalam

${ }^{15}$ Ibid, h. 374.

16 Amir Syarifuddin, Hukum Perkawinan Islam di Indonesia, (Jakarta: Kharisma Putra Utama, 2006), h. 66 
berkomunikasi, selain itu dapat diuji kepandaian akalnya (mumayyiz dapat membedakan satu dengan yang lain) maknanya orang yang melakukan akad itu berakal. ${ }^{17}$ Dengan demikian syarat usia untuk melangsungkan pernikahan yang terdapat dalam kitab-kitab fiqhi adalah berakal, mampu berkomunikasi atau mengerti apa yang diucapkan.

Dalam Undang-Undang No. 1 Tahun 1974 Tentang Perkawinan dalam Bab II Syarat Perkawinan Pasal 7 yaitu "Perkawinan hanya diizinkan apabila pria mencapai umur 19 Tahun dan pihak wanita mencapai umur 16 Tahun. Adapun Dalam UndangUndang No. 16 Tahun 2019 Tentang Perubahan Undang-Undang No. 1 Tahun 1974 Bab II Syarat Perkawinan Pasal 7 yaitu “ Perkawinan hanya diizinkan apabila pria dan wanita mencapai umur 19 Tahun"

Sanksi adat (adat ni soko ni po porongo atau ditangkap dikasi nikah) di Desa Powelua terdapat unsur paksaan yang dimana unsur paksaan tersebut jika masyarakat yang didapati melanggar adat hanya ada dua pilihan antara menikah atau membayar denda ( $g i v u$ ) ada juga dalam keadaan-keadaan tertentu tidak ada pilihan yang ada hanya pernikahan seperti didapat berduaan ditempat gelap, didapati diruangan tertutup dan mengantar seorang perempuan pulang diatas jam 10 malam, maka hal ini menurut pandangan penulis bukan hakikat dari pencegahan zina akan tetapi ada unsur paksaan akibat dari sanksi adat itu sendiri, karena pencegahan yang di maksud menurut hemat penulis tidaklah seharusnya langsung memberikan sanksi (kecuali dalam keadaan tertentu) seperti hamil diluar nikah maka wajib dilaksanakan pernikahan akan tetapi pencegahan berupa nasehat, peringatan atau bimbingan secara khusus bagi yang kedapatan melanggar sanksi adat. Jika dalam sanksi adat itu sendiri terdapat unsur paksaan maka akan dapat menghilangkan keharmonisan dalam berumah tangga sehingga hal ini akan bertentangan dengan tujuan dari pernikahan itu sendiri, hal ini sesuai dengan firman Allah Swt sebagai berikut:

17 Abdul Aziz Muhammad dan Abdul Wahab Sayyed Hawwas, Fiqh Munakahat, (Jakarta: AMZAH, 2011), h. 97 


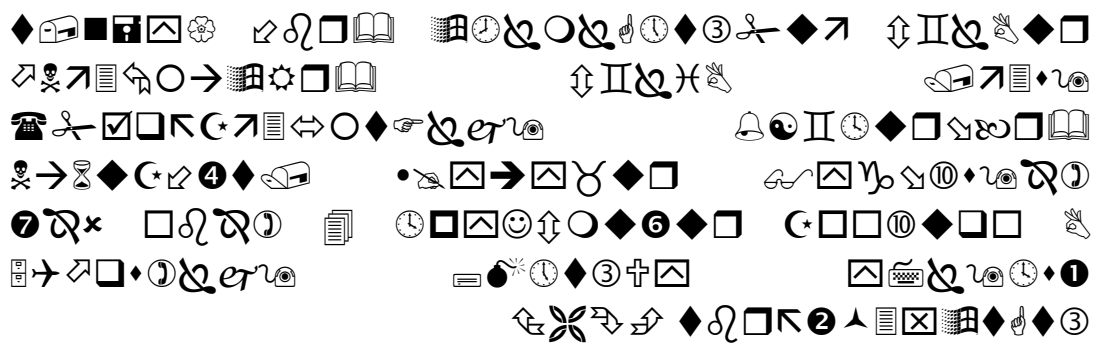

Terjemahan: Dan diantara tanda-tanda kebesarannya ialah dia menciptakan pasangan-pasangan untukmu dari jenismu sendiri agar kamu cenderung dan merasa tenteram kepadanya dan dia menjadikan diantaramu rasa kasih dan sayang. Sungguh pada yang demikian itu benar-benar terdapat tanda-tanda (kebesaran Allah) bagi kaum berpikir. (Q.S Ar-Rum:21). ${ }^{18}$

Ayat diatas mengisyaratkan bahwa tujuan dalam pernikahan adalah membentuk keluarga yang tentram dan menimbulkan rasa kasih dan sayang secara umumnya ayat diatas menunjukkan tujuan umum pernikahan adalah membentuk sebuah bahtera rumah tangga yang sakinah, mawaddah dan warahmah. Dengan demikian jika dalam pernikahan terdapat unsur paksaan maka hal ini bertentangan dengan tujuan pernikahan apalagi pernikahan dini.

\section{Penutup}

Dari hasil peneltian dan pembahasan yang dipaparkan, maka dapat ditarik kesimpulan sebagai berikut;

Pernikahan dini akibat sanksi adat adat (adat ni soko ni po porongo atau ditangkap dikasi nikah) di Desa Poweluwa ini sudah berlaku sebelum penyebaran agama Islam di Sulawesi Tengah khususnya, sanksi adat ini merupakan sanksi adat yang tidak dapat diganggu gugat mulai dari zaman dahulu hingga saat ini. Pernikahan akibat sanksi adat tidak hanya terjadi untuk yang dibawa umur akan tetapi pernikahan akibat sanksi adat ini tidaklah mengenal umur siapa saja yang didapati melanggar sanksi adat maka hanya ada dua pilihan

\footnotetext{
${ }^{18} \mathrm{Ibid}$, h. 574
} 
yaitu membayar denda (givu) atau melakukan pernikahan ( $n i$ soko $n i$ po porongo)

Pernikahan dini akibat sanksi adat (adat ni soko ni po porongo atau ditangkap dikasi nikah) di Desa Poweluwa merupakan sesuatu yang tidak dianjurkan atau bertentangan dengan hukum Islam dan melanggar ketentuan perundan-undangan yang mengatur tentang batasan umur calon mempelai yang diatur dalam UU No. 16 Tahun 2019 apalagi Pernikahan dini akibat sanksi adat (adat ni soko ni po porongo atau ditangkap dikasi nikah) di Desa Poweluwa terdapat unsur paksaan yang dimana unsur paksaan tersebut, jika masyarakat yang didapati melanggar adat hanya ada dua pilihan antara menikah atau membayar denda ( $g i v u$ ) ada juga dalam keadaan-keadaan tertentu tidak ada pilihan yang ada hanya pernikahan seperti didapat berduaan ditempat gelap, didapati diruangan tertutup dan mengantar seorang perempuan pulang diatas jam 10 malam Jika dalam sanksi adat itu sendiri terdapat unsur paksaan maka akan dapat menghilangkan keharmonisan dalam berumah tangga sehingga hal ini akan bertentangan dengan tujuan dari pernikahan dalam Islam. Apalagi dalam pernikahan dini dapat menimbulkan dampak-dampak yang negatif seperti perceraian, perkelahian dalam rumah tangga, khusus bagi perempuan dimana organ-organ reproduksinya belum siap untuk hamil dan melahirkan.

\section{Referensi}

Aziz, Abdul Muhammad Azzam, dan Abdul Wahhab Sayyed Hawwas, Fiqih Munakahat Cet. 2: Jakarta: Amzah, 2011

Agama RI, Departemen, al-Qur'an dan Terjemahan Surabaya: Duta Ilmu, 2002

Al-Hamdani, H.S.A., Risalah Nikah, terjemah Agus Salim Ed. 2, Jakarta: Pustaka Amani, 2002 
Comparativa Vol. 1 No. 1, Januari - Juni 2020

At-Tihami, Muhammad, Terjemahan Qurratul uyun Surabaya: Ampel Mulia, 2004

Abidin, Slamet dan H. Aminuddin, Fiqh Munakahat Bandung: Pustaka Setia, 1999

Ali, Zainuddin, Hukum Islam Ed. 1: Palu: Yayasan Masyarakat Indonesia Baru, 2001

Abdullah, Sulaiman, Sumber Hukum Islam, Jakarta; Sinar Grafika, 1995

Ahmad, Imam bin Muhammad bin Hambal, Musnad Imam Ahmad, Jakarta; Pustaka Azzam, 2008

Aldin (Masyarakat), Wawancara Pribadi di Rumah, 18 September 2020

Al-Hamdani, H.S.A. Risalah Nikah, terjemah Agus Salim Ed. 2, Jakarta: Pustaka Amani, 2002

Al-Qordhawi, Yusuf, Halal dan Haram dalam Islam, Singapura; Pustaka Islamiyah, 1999

BKKBN, Pendewasaan Usia, Jakarta, 1993

Burhan Bungi, H.M, Metode Kualitatif, Jakarta; Kencana, 2010

C Wulansari, Dewi, Hukum Adat Indonesia Suatu Pengantar, Bandung; PT. Refika Aditama

Djalil, A. Basiq, Ilmu Ushul Fiqh (satu atau dua), (Jakarta; Kencana Prenada Media Group, 2010

Djazuli, A. Ilmu Faeiqh: Penggalian, Perkembangan dan Penerapan Hukum Islam, Jakarta; Kencana Prenada Media Group, 2005

Efendi, Satria, Ushul Fiqh, Jakarta; Kencana Prenada Media Group, 2005

Hasan Khalil, Rasyad, Tarikh Tasyri', Jakarta; Amzah, 2009

Hadi Kusuma, Hilman, Hukum Perkawinan Indonesia Menurut Perundangan, Hukum, Adat dan Agama, Bandung: 1990 
Mardani, Ushul Fiqh, Jakarta; PT. Raja Grafindo Persada 2013

Mustari Pide, A. Suriyaman, Hukum Adat, Jakarta: Kencana, 2017

Moelong J, Lexi, Penelitian Kualitatif, Bandung; Remaja Rosdakarya, 1999

Milles B, Matthew, et Al-Qualitative data analisys, diterjemahkan oleh Tjetjep Rohendi rohidi dengan judul analisis data kualitatif, buku sumber tentang metode-metode baru, Cet I, Jakarta; UI Pres, 1992

Mustofa, Syahrul, Hukum Pencegahan Pernikahan Dini, Jakarta: Guepedia, 2019

Margono, S. Metodologi Penelitian Pendidikan, Cet III, Jakarta; Rineka Cipta, 2000

Patilima, Hamid, Metode Penelitian Kualitatif, Bandung; Alfabeta, 2007

Rahman Dahlan, Abd. Ushul Fiqh, Jakarta; AMZAH, 2010

Rianse, Ustman, Metodologi Penelitian Sosial Ekonomi, Bandung; Alfabeta, 2009

Syarifuddin, Amir, Hukum Perkawinan Di Indonesia Ed.1: Jakarta: Kencana, 2006

Syukur, Sarmin, Sumber-Sumber Hukum Islam, Surabaya; Al-Ikhlas 2010

Sulastri, Dewi, Pengantar Hukum Adat, Bandung: Pustaka Setia, 2015

Shufiyah, Fauziatu, "Pernikahan Dini Menurut dan Dampaknya", Jurnal Living Hadis, Volume 3, Nomor 1, Mei 2018

Soekonto, Soerjono, Intisari Hukum Keluarga, Bandung: Citra Aditya Bakti, 1992

Sugiyono, Memahami Penelitian Kualitatif, (Bandung; Alfabeta, 2009

Sugiyono, Metode Penelitian Kualitatif, Kuantitatif, dan $R \& B$, Bandung; Alfabeta, 2010 
Comparativa Vol. 1 No. 1, Januari - Juni 2020

Subadio, Peranan dan Kedudukan Wanita Indonesia, Yogyakarta: UGM Press Subekti, 1987

Suryono, Menuju Tangga Harmonis, Pekalongan: Penerbit TB. Bahagia, 1992

Setiadi, Tolib, Intisari Hukum Adat Indonesia, Bandung: Alfabeta, 2018

Surakhmand, Winarmo, Dasar dan Teknik Research, Pengantar Metodologi Ilmiah, Ed VI, Cet III, Bandung; Tarsito 1985

Tihami, H.M.A., dan Sohari Sahrani, Fikih Munakahat Cet. 2, Jakarta: Rajawali Pres, 2010

Umar, Anas, Panduan Iman dan Pegawai Syara', (Palu; Majlis Dzikir dan Ta'lim Syubbaanul Khairaat, 2016

Wigyodipuro, Asas-Asas dan Susunan Hukum Adat, Jakarta: Penerbit Prandnya Paramita, 1967

Wahhab Khallaf, Abdul, Kaidah-Kaidah Hukum Islam (Ilmu Ushulul Fiqhi), Jakarta; PT. Raja Grafindo Persada, 1996

Yulia, Buku Ajar Hukum Adat, Jakarta: Unimal Press, 2016

Zahro, Abu, Ushul Fiqh, Surabaya; Pustaka Firdaus, 2011

* Mahasiswa prodi ahwal syakhsiyyah Universitas Alkhairaat Palu 